\title{
若年者における近見障害
}

\author{
恒 川幹子（愛知医大）
}

\section{The Near Vision Disturbance in Young Age}

\author{
Mikiko TSUNEKAWA
}

Department of Ophthalmology, Aichi Medical University

I .はじめに

近見作業時には，調節・瞳孔および輻湊が関 与し, 最近の電気生理学の発展により, 近見時 のこれらの諸機能が記録解析されるようになっ た。しかしながら，これらの機能はどれか $1 つ$ を完全に分離できるものではなく相互に関連し あっており，正確なメカニズムという点におい てはまだ不明なことも多い。ことに，若年者に おける近見障害に対する臨床的な研究報告はあ まり例がなく，ほとんどの病院において，通常， 近用凸レンズのメガネを処方しているのが現状 ではないだろうか。

今回，ここ数年の間に本大学病院眼科外来を 訪ずれた若年者近見障害の患者に対して，赤外 、線オプトメーターによる調節機能の他覚的検査 の結果，調節筋の異常ではなく，過剰調節刺激 による調節緊張および安静位の近点側への偏位 が明らかになり，これより輻湊のトレーニング やプリズム眼鏡の処方を行なった所，良好な治 療成績を得たので報告する。

\section{II. 症例および近見視力、}

近見障害を主訴として来院した患者は，昭和 51 年12月〜昭和 54 年 8 月の間に 5 例であった。 その年齢，性別および近見視力は表 1 の通りで ある。症例 $\mathrm{V}$ は，視力は良好であるが近見作業 時の頭痛, 疲労感が主訴であった。

\section{III. 検査およびその評価}

若年者において，近見障害を主訴として来院 した患者に対して次のような検查を行なった。

連絡先（干480-11）愛知郡長久手町大字岩作字雁又
表 1. 近 見 視 力

\begin{tabular}{|c|c|c|c|}
\hline 症 例 & 年 令 & 性 別 & 近 見 視 力 \\
\hline I & 10 才 & 女 & $\begin{array}{l}\text { V.D. }=0.2(1.2 \times+3.0 \mathrm{D}) \\
\text { V.S. }=0.2(1.2 \times+3.0 \mathrm{D})\end{array}$ \\
\hline II & 13 才 & 女 & $\begin{array}{l}\text { V.D. }=0.15(1.0 \times+1.75 \mathrm{D}) \\
\text { V.S. }=0.15(1.0 \times+1.75 \mathrm{D})\end{array}$ \\
\hline III & 14 才 & 女 & $\begin{array}{l}\text { V.D. }=0.2(1.2 \times+3.0 \mathrm{D}) \\
\text { V.S. }=0.2(1.2 \times+3.5 \mathrm{D})\end{array}$ \\
\hline IV & 15 才 & 女 & $\begin{array}{l}\text { V.D. }=0.1(1.2 \times+2.0 \mathrm{D}) \\
\text { V.S. }=0.1(1.2 \times+2.5 \mathrm{D})\end{array}$ \\
\hline $\mathrm{V}$ & 17 才 & 男 & $\begin{array}{l}\text { V.D. }=1.0(\mathrm{n} . \mathrm{c})(\text { 近見時疲学感 }) \\
\text { V.S. }=1.0(\mathrm{n} . \mathrm{c})\end{array}$ \\
\hline
\end{tabular}

1. 角膜 - 中間透光体 $\cdot$ 眼底検査

2 . 視力検査（遠見・近見）

3 . 屈折検査

4. 眼位検查

5. $\mathrm{AC} / \mathrm{A}$ 比

6 . 融像幅

7 . 眼球運動検査

8 . 輻湊近点

9. 調節機能検査

調節力・アコモドグラム・

瞳孔調節電図

このうち屈折検査は, 普通瞳孔時のスキア法 にて行なった。屈折検査の結果と遠見視力は表 2 に示す通りである。屈折検査の結果と遠見視 力には，特徵的な傾向は見られなかった。

眼位検査はA.P.C.T.にて行なった。結果は 表 3 に示す通りである。症例IIIは間歇性外斜視 のタイプであるが，残りの 4 症例は遠見眼位は 正位，近見眼位は外斜位となっている。

$\mathrm{AC} / \mathrm{A}$ 比の検査は，症例によって方法はそ れぞれ異なっているが，現在一般に行なわれて 
表 2. 遠見視力 他覚的屈折検査（普通瞳孔スキア）

\begin{tabular}{|c|c|c|c|c|c|}
\hline \multirow{2}{*}{ 症 例 } & \multirow{2}{*}{ 年 令 } & \multirow{2}{*}{ 性 別 } & \multirow{2}{*}{ 遠 見 視 力 } & 屈 & 折 \\
\hline & & & & $\bar{R}$ & $\overline{\mathrm{L}}$ \\
\hline I & $10 才$ & 女 & $\begin{array}{l}\text { V.D. }=1.5 \\
\text { V.S. }=1.5\end{array}$ & $\mathrm{E}$ & E \\
\hline 【I & $13 才$ & 女 & $\begin{array}{l}\text { V.D. }=0.08(1.2 \times-1.5 \mathrm{D}) \\
\mathrm{V} . \mathrm{S}_{\mathrm{*}}=0.08(1.2 \times-1.5 \mathrm{D})\end{array}$ & -1.5 & -1.5 \\
\hline III & 14 才 & 女 & $\begin{array}{l}\mathrm{V} . \mathrm{D}_{\mathbf{1}}=1.0 \\
\mathrm{~V} . \mathrm{S} .=0.7(1.0 \times+1.0 \mathrm{D})\end{array}$ & $\mathrm{E}$ & $+0.5 \mathrm{D}$ \\
\hline IV & 15 才 & 女 & $\begin{array}{l}\text { V.D. }=0.9(1.2 \times-0.25 \mathrm{D}) \\
\mathrm{V} . \mathrm{S} .=0.7(1.2 \times-0.25 \mathrm{D})\end{array}$ & $E \sim+0.5 \mathrm{D}$ & $L^{-0.5 \mathrm{D}}$ \\
\hline$V$ & $17 才$ & 男 & $\begin{array}{l}\mathrm{V} . \mathrm{D}_{\mathrm{S}}=1.0 \\
\mathrm{~V} . \mathrm{S}_{\cdot}=0.9 \\
(1.2 \mathrm{pX}-025 \mathrm{D}-\mathrm{cyl}-0.25 \mathrm{D} \uparrow)\end{array}$ & $\mathrm{E}$ & $\begin{array}{l}-0.25 \mathrm{D} \\
L_{-0.5 \mathrm{D}}\end{array}$ \\
\hline
\end{tabular}

表 3. 眼位 (A.P.C.T.)

\begin{tabular}{|c|c|c|c|c|}
\hline \multirow{2}{*}{ 症 例 } & \multirow{2}{*}{ 年 令 } & \multirow{2}{*}{ 性 別 } & \multirow{2}{*}{ 眼 } & 位 \\
\hline & & & & D \\
\hline I & $10 才$ & 女 & $6 \Delta X$ & or tho \\
\hline II & 13 才 & 女 & $6 \Delta x$ & ortho \\
\hline III & 14 才 & 女 & $20 \triangle \mathrm{X}$ & $20 \triangle \mathrm{XT}$ \\
\hline IV & 15 才 & 女 & $6 \Delta x$ & ortho \\
\hline V & 17 才 & 男 & $8 \triangle X$ & ortho \\
\hline
\end{tabular}

表 4. A C / A 比 $(\triangle / \mathrm{D})$

\begin{tabular}{|l|c|c|c|c|c|}
\hline 症例 & 年 令 & 性 別 & Hetero. & Gradi. & Synopt. \\
\hline I & 10 才 & 女 & 3.7 & 2.0 & \\
\hline II & 13 才 & 女 & 4.2 & 4.0 & \\
\hline III & 14 才 & 女 & 1.0 & & \\
\hline IV & 15 才 & 女 & & & 2.0 \\
\hline V & 17 才 & 男 & 3.6 & 2.0 & 2.0 \\
\hline
\end{tabular}

いる Gradient 法, Heterophoria 法, Synoptophore を用いる方法のいずれかで行なった。結果 は表 4 に示す通りである。 $\mathrm{AC} / \mathrm{A}$ 比の正常值

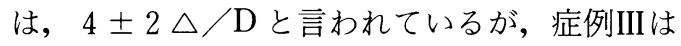
$1 \triangle / \mathrm{D}$ と明らかに低下しており, 症例 I , IV, $\mathrm{V}$ も方法によっては $2 \triangle / \mathrm{D}$ と低值を示してい る。Heterophoria 法と Gradient 法を併わせて 行なった症例では, Heterophoria 法による值の
表 5. 輻湊近点 $(\mathrm{cm})$ 融像幅 $\left({ }^{\circ}\right)$

\begin{tabular}{|l|c|c|c|c|}
\hline 症例 & 年 令 & 性 別 & 輻湊近点 & 融 像 巾 \\
\hline I & 10 才 & 女 & 8 & $-6 \sim+6$ \\
\hline II & 13 才 & 女 & 5 & $-6 \sim+18$ \\
\hline III & 14 才 & 女 & 18 & $-6 \sim+7$ \\
\hline V & 15 才 & 女 & & \\
\hline V & 17 才 & 男 & 5 & $-6 \sim+20$ \\
\hline
\end{tabular}

方が高く出ているが，これは近接性輻湊が含ま れたものと思われる。

融像幅の検査はシノプトフォアの融像図形を 用いて検査した。結果は表 5 に示す通りである。 正常成人の融像幅は, シノプトフォアを用いた 白井の報告によれば, 約 $-3 \circ \sim+12^{\circ}$ と言われて いる。症例 I, IIIは輻湊側の融像幅が低下して いる。

眼球運動はペンライトを用い, ひき運動・む き運動の検査をスクリーニング的に行なった。

輻湊近点はペンライトを用い, 正中線に沿っ てゆっくりと視標を鼻根部に向って接近させ， 輻湊眼位のくずれた点とした。結果は表 5 に示 す通りである。輻湊近点は一般に $7 \sim 8 \mathrm{~cm}, 10$ $\mathrm{cm}$ 以内であれば正常とするが，症例IIIを除い て I，II，Vは正常である。

調節力は石原式近点計を用いて遠点, 近点を 測定し換算した。結果は表 6 に示す通りである。 この年代の正常な調節力は $8 \sim 10 \mathrm{D}$ であるが, 症例 I 〜 IVは明らかに低下している。症例 Vは， ほぼ正常な調節力であるが, 症例 Vの主訴は近 見作業時の頭痛および疲労感であり, 近見障害 まではきたしていないということと一致する。

アコモドグラムはアコモドポリレコーダーを 用いて検査した。全例に緊張時間の延長があり， いわゆる老視 type が見られた。

瞳孔調節電図は赤外線オプトメーターAS III を用いて検査した。調節緊張, 弛緩運動は一般 的に良好であり, 潜時にも異常なく, 微動調節・ 周波数も正常分布を示し, 調節筋異常は認めな かったが，全例において安静位の近点側への偏 
表 6. 調 節 力 (D)

\begin{tabular}{|c|c|c|c|c|}
\hline \multirow{2}{*}{ 症 例 } & \multirow{2}{*}{ 年 令 } & \multirow{2}{*}{ 性 別 } & \multicolumn{2}{|c|}{ 調 節 } \\
\cline { 4 - 5 } I & 10 力 & 女 & 1.4 & 2.0 \\
\hline II & 13 女 & 女 & 1.0 & 1.0 \\
\hline II & 14 才 & 女 & 2.0 & 2.5 \\
\hline IV & 15 才 & 女 & 1.75 & 0.5 \\
\hline$V$ & 17 オ & 男 & 10.0 & 6.9 \\
\hline
\end{tabular}

位が見られた。

\section{IV．治療および経過}

若年者近見障害に対して，表 7 に示すように プリズム眼鏡を処方した。症例IIIについては良 好な近見視の得られるプリズムの度が両眼合わ せて24 $\triangle$ と多いことや，眼鏡装用に対する抵抗 が強く輻湊不全もあったことから, 輻湊および 融像のトレーニングを指示した。

プリズム眼鏡を処方した症例では，プリズム 眼鏡を装用しはじめてから 2 週間程で眼鏡装用 による良好な近見視が得られた。また症例 II, III は，治療を開始して 2 力月程で裸眼でも良好な 近見視が得られた。一方, 調節機能も著しく改 善された。

\section{〈プリズム眼鏡を処方する場合〉}

プリズム眼鏡を処方する場合，気をつける点 として，1）最高で近見時の外斜位の度をこえ ない，2）通常は近見時の外斜位の度の半分を めやすとする，3)両眼に均等に分ける，4)+ レンズを加入する場合，遠見視に支障をきたさ ず，かつ良好な近見視の得られる最弱度のレン ズとする，などがあげられる。また，装用テス トは時間をかけて行ない, 処方にあたっては治 療用眼鏡としての装用の意義，必要性を患者に， 説明し, 納得させることが大切である。

\section{$\mathrm{V}$ ，症例}

近見障害を主訴として来院し, 輻湊および融 像のトレーニングやプリズム眼鏡の装用で良好 な治療経過を呈した 2 症例を紹介する。
表 7. 治 療・経 過

\begin{tabular}{|c|c|c|c|c|}
\hline 症 例 & 年 令 & 性 別 & 療 & 近見視力 \\
\hline I & 10 才 & 女 & $\begin{array}{l}\text { メガネ処方 } \\
\text { B) }+0.75 \mathrm{D}=3 \Delta \text { Base in }\end{array}$ & $(1.0)$ \\
\hline II & 13 才 & 女 & $\begin{array}{l}\text { メガネ処方 } \\
B)+0.25 D=1 \triangle \text { Base in }\end{array}$ & 1.0 \\
\hline III & 14 才 & 女 & 輻湊 ・ 融像のトレーニング & 1.0 \\
\hline IV & 15 才 & 女 & $\begin{array}{l}\text { メガネ処方 } \\
\text { B) } 1.5 \triangle \text { Base in }\end{array}$ & $(0.9)$ \\
\hline V & $17 才$ & 男 & $\begin{array}{l}\text { メガネ処方 } \\
\text { B) } 0.5 \triangle \text { Base in }\end{array}$ & $(1.0)$ \\
\hline
\end{tabular}

（）：メガネ装用によろ近見両眼視力

症例 1 14歳 女子

初診：昭和 51 年 12 月 6 日

現病歴：8月頃より, 何の誘因もなく突然近 くのものが見にくくなり，近医にて様子を見て いたが，改善しないため紹介されて来院した。

家族歴：異常なし

既応歴：近見障害をきたした頃より耳鳴が出 現し，耳鼻科受診の結果，慢性副鼻腔炎と診断 された。

初診時所見：

視力 F. V.

$$
\begin{aligned}
& \text { V.D. }=1.0, \hat{V} . S_{.}=0.7(1.0 \times+0.5 \mathrm{D}) \\
& \text { N. V. } \\
& \text { V. D. }=0.2(1.2 \times+3.0 \mathrm{D}) \\
& \text { V.S. }=0.2(1.2 \times+3.0 \mathrm{D})
\end{aligned}
$$

屈折検査 $(\mathrm{SK})$ 右眼 $\mathrm{E}$, 左眼 $+0.5 \mathrm{D}$

眼位(A.P.C.T.) N : 20 $\triangle$ X, D : 20 $\triangle$ XT Synoptophore : I $(+)$ subj.A. $=-10^{\circ}$ obj.A. $=-10^{\circ}$

$$
\begin{aligned}
& \text { II }(+) \quad-6^{\circ} \sim+6^{\circ} \\
& \text { III }(+)
\end{aligned}
$$

$\mathrm{AC} / \mathrm{A}$ 比 : $1 \triangle / \mathrm{D}$

輻湊近点 $18 \mathrm{~cm}$

調節機能 調節力: $\mathrm{R}=2.0 \mathrm{D}, \mathrm{L}=2.5 \mathrm{D}$

調節時間：弛緩・緊張ともに延長

角膜：軽度のびまん性表層角膜炎

中間透光体・眼底・眼球運動異常なし 治療・経過：

遠視十外斜位による近見障害と考え，プリズ ム眼鏡装用テストを主体に, $\mathrm{B}_{1}, \mathrm{~B}_{6}, \mathrm{~B}_{12}$ 複合剤・ 
$\mathrm{ATP} \cdot \mathrm{B}_{12}$ の点眼を投与し, 経過をみたが最初改 善の兆しがなく治療に苦慮した。一方慢性副鼻 腔炎の外来治療も並行して行なった。

1 力月後, プリズム眼鏡装用テストにて N. $V_{.}=(1.0 \times 24 \triangle$ Base in $)$ と良好な近見視が得 られたが，眼鏡を装用することに抵抗が強かっ たため, 家庭内における輻湊や融像のトレーニ ングを指示した。訓練を始めて 1 力月後には, 遠見視力右 1.2 , 左 1.2 , 近見視力右 $0.8(1.0 \times+$ $0.5 \mathrm{D})$, 左 $0.6(1.0 \times+0.5 \mathrm{D})$ となり, 調節機能 も著しく改善, 輻湊近点も動摇はあるが $10 \mathrm{~cm}$ と改善した。さらに 2 力月後には近見視力が両 眼とも 1.0 となり，自覚症状もほとんど消失し， 調節力も右 $=8.5 \mathrm{D}$, 左 $=6.6 \mathrm{D}$ と回復, 輻湊近点 も to nose となった。

本症例は, 外斜位に併わせて輻湊不全の存在 が近見障害の原因と思われた症例で，輻湊・融 像のトレーニングで良好な近見視が得られた。

\section{症例 2 13歳 女子}

\section{初診：昭和 54 年 8 月 31 日}

現病歴： $2 \sim 3$ 年前より視力の動摇が激しく 近医で仮眼鏡を作成したが，突然近見障害をき たし，紹介されて来院した。

家族歴，既応歴には特記すべきことなし。 初診時所見：

視力 F.V.

$$
\begin{aligned}
& \text { V.D. }=0.08(1.0 \times-1.5 \mathrm{D}) \\
& \text { V.S. }=0.08(1.0 \times-1.5 \mathrm{D}) \\
& \text { N. V. } \\
& \text { V.D. }=0.15(1.0 \times+1.75 \mathrm{D}) \\
& \text { V.S. }=0.15(1.0 \times+1.75 \mathrm{D})
\end{aligned}
$$

屈折検査 $(\mathrm{SK})$ 右眼 $-1.5 \mathrm{D}$, 左眼 $-1.5 \mathrm{D}$ 眼位 (A.P.C.T.) N : $6 \triangle \mathrm{X}, \mathrm{D}$ : ortho Synoptophore $: I(+) \quad$ subj. $A .=-3^{\circ}$ obj.A. $=-10^{\circ}$

$$
\begin{aligned}
& \text { II }(+) \quad-6^{\circ} \sim+18^{\circ} \\
& \text { III }(+)
\end{aligned}
$$

$\mathrm{AC} / \mathrm{A}$ 比 : $4 \triangle / \mathrm{D}$

輻湊近点 $5 \mathrm{~cm}$

調節機能 調節力: $\mathrm{R}=1.0 \mathrm{D}, \mathrm{L}=1.0 \mathrm{D}$

$$
\mathrm{I} \cdot \mathrm{R} \cdot \mathrm{O} \text { : 安静位で近点側に偏位 }
$$

角膜 -中間透光体・眼底・眼球運動異常なし

\section{治療・経過：}

初診日より 1 週間後, 両眼に+0.25D=1 $\triangle$ Base inのレンズを装用させた所，遠見両眼視 力 $\mathrm{B} . \mathrm{V}=(1.0 \times$ glass $)$, 近見両眼視力 $\mathrm{B} . \mathrm{V} .=$ (0.6p $\times$ glass) を得たので眼鏡を処方した。

1 力月後, 眼鏡装用にて遠見, 近見ともに1.0の 視力となり，さらに眼鏡装用を始めて約 2 力月 後には, 遠見, 近見ともに裸眼にて1.0の視力を 得た。また, 調節力も， R L ともに $10 \mathrm{D}$ に回復 した。患者は症状が改善したので眼鏡をはずす ことを望んでいるが, 調節機能検査において非 装用時の緊張状態がいまだ改善されていないた め, 近見作業時の装用を指示し経過観察中であ る。

\section{VI. 考 察}

我々が経験した若年者近見障害の全例に共通 した点は外斜位の存在であり，またプリズムに よって症状が改善されたということから考えて も，キーポイントであるということは一目瞭然 であるが, 調節機能の検査結果における特有な 調節の状態の存在によってその診断が可能とな り, プリズム量なども調節機能と合わせ判断す る必要がある。それならどのような機序で, 近 見障害がひき起こされてゆくのであろうか。四 示して考察を加えてゆきたい（図 1 ）。

患者の眼は日常視下で遠見眼位は正位である

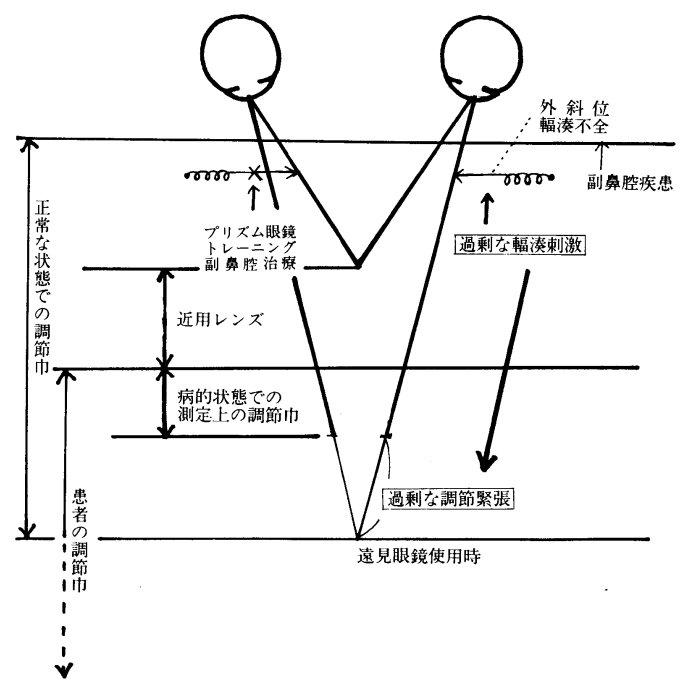

図 1 . 
が，その眼位を保つために元来の外斜位や輻湊 不全に打ち勝とうと強い過剰な輻湊刺激が伝わ る。しかし輻湊と調節は相互に作用しあってい るため, 患者の眼には過䛢な調節緊張の状態を も誘発され，遠見時にすでに調節したような状 態で日常視するようになり,この異常な緊張状 態が習慣化されていくうちに（この状態は瞳孔 調節電図によって診断可能である）輻湊と調節 の病的アンバランス状態を作り出し, 調節系の 機能低下をひき起こしてゆく。機能低下に加え て，遠見時にすでに調節緊張の状態になってい るため，近見時にさらに調節しようとしても予 備能力は少なく，近見障害をきたしてゆくと思 われる。図で言えば外斜位や輻湊不全がバネの ような役目を果たし，そのバネの力が強いため バネの力に抗して眼位を正位に保とうとして， 過剩な輻湊刺激が伝わってゆくのであろう。

鈴村はこのような外斜位の自己矯正能による 強い内よせに伴う近視化状態を，内よせ性調節 緊張と呼び, 若年者における近見時眼精疲労や 近見障害の原因としている。

松崎, 神前らの研究でも, 輻湊不全や輻湊不 足といった輻湊障害がある場合, 患者は近業時 の疲労感，頭痛などを訴えるとしている。また さらに融像性輻湊の増強訓練を行なうことによ って，そういった症状の軽減あるいは消失が見 られ，近視化傾向のものの遠見霧視が消失し， 視力の良転が得られる場合もあると述べている。

一方, 足川, 楢崎らは, 輻湊障害や輻湊に伴 う瞳孔の近見反応障害が副鼻腔疾患と密接に関 連しており，耳鼻科的療法によって眼科的所見 も改善した症例について報告している。私達の 症例でも，輻湊不全の見られた症例では慢性副 鼻腔炎が見られ，眼科的治療に併わせて耳鼻科 外来治療も行なった。若年者近見障害を経験す るような場合, 原因治療の 1 つとして耳鼻科的 検索の必要性も忘れてはならない。

\section{VII. まとめ}

近見障害を主訴として来院した10～17歳まで の患者に対し, 種々の検査の結果, 輻湊・融像 のトレーニングやプリズム眼鏡による治療を行 なった所，近見障害が改善した症例を経験した。
従来まではこのような患者に対する治療として, 近用凸レンズの処方によって日常の不便さをと りのぞいてやるだけの方法が一般的なようであ るが, 我々の試みたプリズム療法は主訴を軽減 もしくは消失させるというだけでなく，原因治 療としての面をも併せもっている点で意義が大 きいと思われたので報告した。

稿を終えるにあたり，ご指導，ご校閲を賜わ りました鈴村昭弘教授に深謝致します。

\section{文献}

1. Burian, H.M., and Von Noorden, G. K. : Binocular vision and ocular motility. Mosby, Saint Louis, 1974.

2. 鈴村昭弘：屈折異常と眼精疲労. 眼科, 21 巻, 1979 .

3. 神前正敬：輻湊抒よび $\mathrm{AC} / \mathrm{A}$ 比測定. 眼科 Mook, No. 3, 1979.

4. 松崎 浩, 神前正敬：輻湊とその障害. 明日の眼 科展望'77，金原出版，1977。

5 . 弓削経一 他編：視能矯正一理論と実際一. 金原出 版, 1973.

6. 足川力雄, 楢崎嗣郎, 鈴木羊三, 清水春一: 輻湊 障害の治療法に関する鼻科学的研究. 眼科臨床医報, 72 巻 5 号, 1978 .

7. 足川力雄, 大前 隆, 楢崎嗣郎, 清水春一, 坂田 英治：鼻腔整復術および半月神経節，翼口蓋神経節 Blockによる，輻湊㧍よび輻湊に伴う瞳孔の近見反 応障害の改善について. 耳展誌, 19 巻 2 号, 1976.

\section{質問} （順天堂大）川村 緑

1. 近視障害の中主板節の疲労現象が一次的な調節 障害と, 輻湊不全が一次的にあり, 二次的に調節障害 をおこしている例をみる。それがはっきり分けられな い caseも勿論多い。その区別をどういうふうにとられ ているか教えていただきたい。

2.プリズム眼鏡の処方をどのように処方されたか， 例えば, 来院時に適当と思われれば直ちに処方を行な うか。

3.プリズム眼鏡は装用させた例はあり，次の段階 として減すこと，あるいは，はずすことを考えると思 うが, はずし方はどのように考えていらっしゃるか, また期間的にも扮教え下さい。

答弁 1 。近点計による調節力の検査では明らかに低 下していましたが, アコモドポリレコーダーや赤外線 オプトメーターによる調節機能検查では, 調節筋麻痺 の所見は見られませんでした。 
2. 他医にて, 半年 1 年経過観察の上, 紹介され た患者ばかりでしたし，調節系そのものに，麻㽻・疲 労等の所見は見られませんでしたので，装用テストを $2 \sim 3$ 回行なった上, 処方致しました。

3. プリズム眼鏡を処方して, まだ期間が短いので, 今後の課題だと思いますが，はずれる症例とはずれな い症例とあるように思います。

\section{質問 （国立小児病院）最上斉子}

若年者に打ける近見障害の原因としては, 遺伝性の 調節不全が50\%位あり，全身的な体力低下に伴うもの も多いと思います。今回, ご発表の中でも， 5 例中 4 例に, 調節力低下があるようですが, 遺伝的なこと, 全身的な疲労については，いかがでしたか。 訓練を中止した後，戻ってしまうようなことは，ご
ざいませんでしたか。

また, prism 眼鏡を使用されていますが, eatup は見 られませんでしたか。

答弁 訓練をした症例は, 間歇性外斜視の型でしたが, 家族も本人も来院するまで斜視に気づいていなかった ようで, 手術的療法やメガネの装用に対する抵抗も強 く, 訓練療法を採用しましたが, 現在の所, 再発はし ていないようです。

質問 （愛知総保セ）伊藤照子 訓練はどれくらいの時間行なわれたのでしょうか。 答弁 5 例中, 訓練をやったのは1例ですが, 輻湊, 融 像のトレーニングを 1 日 $2 \sim 3$ 回，10分ずつ位行なう ように指示し， 2 力月程して，遠見，近見共に良好な 視力が得られました。 